\title{
IN VITRO DEVELOPMENT AND ACCLIMATIZATION OF DENDEZEIRO (Elaeis guineensis) ${ }^{1}$
}

\author{
Marlúcia Souza Souza Pádua ${ }^{2}$, Luciano Viela Paiva ${ }^{3}$, Luis Gustavo Texeira da Silva ${ }^{4}$, Luciano Coutinho
} Silva $^{5}$ e Vanessa Cristina Stein ${ }^{6}$

\begin{abstract}
RESUMO - Fruits and almond from the dendezeiro, oil palmbelonging to the Elaeis genus, are widely used for the production of cookingoils or for the pharmaceutical and cosmetic industries. In the last decade, this oil palm also emerged as a promising source for commercialbiofuel production. This study evaluated the effect of different culture media, MS (MURASHIGUE AND SKOOG) and Y3 (EEUWENS)and carbohydrates duringin vitro germination of zygotic embryos, the effect of growth regulators $\mathrm{GA}_{3}$, NAA and BA Ponin vitro seedling development, and the survival rate of acclimatized seedlingsof Manicoré hybrid (Elaeis oleifera $x$ E. guineensis). Zygotic embryos were inoculated on MS and modified Y3 media, supplemented with different sucrose concentrations $\left(30,45\right.$, and $\left.60 \mathrm{gL}^{-1}\right)$ or sorbitol $\left(36 \mathrm{gL}^{-1}\right)$, and the germination rate was evaluated after 30 days. Subsequently, seedlings were transferred to modified $\mathrm{Y} 3$ culture medium supplemented with differentGA $\mathrm{A}_{3}$ concentrations ( 3.5 and $7 \mathrm{mgL}^{-1}$ ) or without it, combined or not with $1 \mathrm{mgL}^{-1}$ of NAA, $5 \mathrm{mgL}^{-1}$ of BAP. The highest germinationpercentage of germinated embryos $(92 \%)$ was observed in MS medium supplemented with $36 \mathrm{gL}^{-1}$ sorbitol. Culture media supplemented with growth regulatorsGA $\mathrm{A}_{3}$ NAA and BAP promoted greater shoot lengththan control media. Rooted seedlings showed high survival percentage (85\%) during acclimatization.
\end{abstract}

Palavras-chave: Germination; Carbohydrates; Growth regulators.

\section{DESENVOLVIMENTO IN VITRO E ACLIMATIZAÇÃO DE PLÂNTULAS DE DENDEZEIRO}

\begin{abstract}
Frutos e amêndoas de dendezeiro, uma palmeira pertencente ao gênero Elaeis, são amplamente usados para a produção de óleos culinários ou para as indústrias farmacêutica e de cosméticos. Na última década esta palmeira oleifera também emergiu como fonte promissora para a produção comercial de biocombustiveis. Os objetivos deste trabalho foram avaliar o efeito de diferentes meios de cultura, MS (MURASHIGUE; SKOOG) eY3 (EEUWENS) e de carboidratos na germinação in vitro de embriões zigóticos, o efeito dos reguladores de crescimento A $_{3}$, ANA e BAP no desenvolvimento das plântulas in vitro e a taxa de sobrevivência dessas quando aclimatizadasdohíbrido Manicoré(Elaeis oleifera $x$ E. guineensis). Embriões zigóticos foram inoculados em meio de cultivo MS e Y3 modificado, suplementados com diferentes concentrações de sacarose (30, 45 e $\left.60 \mathrm{gL}^{-1}\right)$ ou sorbitol $\left(36 \mathrm{gL}^{-1}\right)$ e, após 30 dias a taxa de germinação foi avaliada. Posteriormente, as plântulas foram transferidas para meio de cultivo Y3 modificado suplementado com diferentes concentrações de $\mathrm{GA}_{3}$ (3,5 e $\left.7 \mathrm{mgL}^{-1}\right)$ ou sem, combinadas ou não com $1 \mathrm{mgL}^{-1}$ de ANA,5 $\mathrm{mgL}^{-1}$ de BAP. A maior porcentagem de embriões germinados (92\%) foi obtida em meio de cultivo MS suplementado com $36 \mathrm{gL}^{-1}$ de sorbitol.
\end{abstract}

\footnotetext{
${ }^{1}$ Recebido em 11.12.2013 aceito para publicação em 02.10.2014.

${ }^{2}$ Programa de Pós-Graduação em Biotecnologia Vegetal, Universidade Federal de Lavras, UFLA, MG - Brasil. E-mail: <marluciabio@yahoo.com.br>.

${ }^{3}$ Departamento de Química, Universidade Federal de Lavras, UFLA, MG - Brasil. E-mail: <luciano@dqi.ufla.br>.

${ }^{4}$ Mestrado em Biotecnologia Vegetal, Universidade Federal de Lavras,UFLA, MG - Brasil. E -mail: <lgustavots@gmail.com>.

${ }^{5}$ Doutorado em Fisiologia Vegetal, Universidade Federal de Lavras, UFLA, MG - Brasil. E-mail: <lucoutsilva@yahoo.com.br>.

${ }^{6}$ Unidade especial de Ciências Biológicas, Universidade Federal de Goiás, UFG, MG - Brasil. E-mail: <vanessa.stein@hotmail.com>.
} 


\begin{abstract}
Os meios de cultivo suplementados com reguladores de crescimento $G A_{3}$, ANA e BAP promoveram maior comprimento da parte aéreaque os meios sem reguladores. As plântulas com raiz apresentaram a maior porcentagem de sobrevivência (85\%) durante a aclimatização.
\end{abstract}

Keywords: Germinação;Carboidratos;Reguladores de crescimento.

\section{INTRODUCTION}

Petroleum-based fuels are the main source of energy in the world, but increased environmental concerns and the predictions of its extinction increases the need for new energy sources, preferably renewable ones (TASHTOUSH et al., 2003; SOARES et al., 2011; RAE; BRADLEY, 2013). Biofuel production using oil plants is a good alternative for a renewable and biodegradable fuel. Brazil stands out in this scenario due toits large territorial dimensions, edaphic and climatic diversity and its many exploitable plant species for this purpose (SOARES et al., 2011).

Among various species of oil plants, palm trees are the most promising for biodiesel production (NUNES et al., 2008; SOARES et al., 2011). Particularly, the oil palm (ElaeisguineensisJacq.) commonly known as "dendê" stands out as one of the most productive oil crops. Yielding on average of oil production about $6.000 \mathrm{~kg} /$ hectare, which corresponds to 1.5 times the yield of coconut oil, twice the olive oil, and more than ten times thesoybean oil production, this oil palm is a promising source for commercial biofuel production (FURLAN et al., 2003; LIN et al., 2009).

Besides the prospect of the use of dendê oil for biofuel production, two other types of oils are already exploited for other purposes. Oneoil typeis extracted from the fruit pulp and the other from the almond (BOARI, 2008; KONAN et al., 2005). The fruit pulp oil is widely used as a cooking oil and the almond oilis used by the pharmaceutical, cosmetic and perfumery industries(BOARI, 2008; FURLAN et al., 2003; KONAN et al., 2005).

Dueto the economic importance of oil palm, breeding studies have developed hybrids with economic traits of interest. Crossing between the African species $E$. guineensis and the American E. oleifera generated the hybrid BRS Manicoré, obtained by Brazilian company Embrapa-AmazôniaOcidental.

The main features inherited from E. oleifera are resistance to lethal yellowing (COLLARES, 2011) a disease associated with phytoplasmas (BEAKBANE et al., 1972), small size and bioenergy oil quality, while high oil production was inherited from E. guineensis (COLLARES, 2011). Thus, this hybrid presents a great commercial interest, generating a high demand for seeds, which is the main form of oil palm propagation. However, E. guineensisdisplays seed dormancy with germination occurring within 1-3 years, besides the low germination rate (no more than 30\%) (MARTINE et. al., 2009; LUIS et al., 2010). These factors hinder the process to obtain seedlings on a commercial scale and consequently the implementation of new crops.

In order to accelerate seedling production on a commercial scale, culture of zygotic embryos can be favorable for reducing germination time and obtaining vigorous, healthy seedlings (SOARES et al., 2011). The culture medium composition, source and amount of carbohydrates in in vitro culture are determinant factors for increased in vitro embryo germination (HU; FERREIRA, 1998; REGO-OLIVEIRA etal., 2003; TRUONG et al., 2013).

In addition,carbohydrates are commonly used in tissue culture (sucrose, fructose, glucose, galactose etc.), sorbitol is also added as an energy source in the culture mediumfor oil palm embryosgermination, moreover, this sugar promoted $100 \%$ germination of ElaeisguineensisJacq. var. Tenerasomatic embryos (TECHATO;HILAE, 2007).

In vitro environment normally has high relative humidity, low light intensity and reduced gas exchange, resulting in low rates of transpiration and photosynthesis of micropropagated plants (SHIN et al., 2013). During the acclimatization in a greenhouse, some morphological, anatomical and physiological changes will occur, making plants able to grow in this new environment. This process may cause stress in plants thus limiting seedling production. Thus, physiological features as well as acclimatization conditions are extremely important to successful largescale production of seedlings (BARBOZA et al., 2006). The aims of this study were: (i) to evaluate the in vitro germination of BRS Manicoré hybrid(Elaeisguineensis x E.oleifera) zygotic embryos in two culture media

Revista Árvore, Viçosa-MG, v.38, n.6, p.1095-1102, 2014 
supplemented with different carbohydrate sources; (ii) evaluate the effect of growth regulators on in vitroseedling development; and (iii) evaluate the survival rates of plants during acclimatization phase.

\section{MATERIALAND METHODS}

\subsection{Plant material}

The trial was performed at the Central Laboratory of Molecular Biology, Federal University of Lavras, state of Minas Gerais, Brazil. Immature fruits of Elaeisoleifera x E. guineensis hybrid BRS Manicoré were provided by Denpasa Company, state of Pará, 90 to 100 days after pollination.

Fruits were first washed in sodium hypochlorite ( $1.25 \%$ active chlorine), opened with the aid of a vice grip to remove epicarp, mesocarp and endocarp. The almonds were extracted and rinsed in tap water before decontamination in a laminar flow hood by immersion in $70 \%$ alcohol for 30 seconds following by plunge for $20 \mathrm{~min}$ into $100 \mathrm{~mL}$ of a sodium hypochlorite solution ( $1.25 \%$ active chlorine) containing three drops of Tween. Subsequently, the almonds were rinsed three timesin sterile water, five minutes each, with continuous stirring.

\subsection{Effect of differentculture mediaandsucrose concentrationson germinationof zygotic embryos}

Decontaminated embryos were isolated from the almonds and inoculated in Petri dishes containing 45 mL of culture medium. MS (MURASHIGE; SKOOG 1962) and modified Y3 (EEUWENS, 1976) culture media were tested with different carbohydrate concentrations: sucrose $\left(30,45,60 \mathrm{gL}^{-1}\right)$ and sorbitol $\left(36 \mathrm{gL}^{-1}\right)$ and a control without carbohydrate.

Embryos were maintained under a 16-hour photoperiod at $26 \pm 2{ }^{\circ} \mathrm{C}$ for 30 days after inoculation and then germination rate was evaluated. The experiment was conducted in a $2 \times 5$ factorial arrangement of treatments in a randomized block design, with five replicates of five embryos each per treatment. Data analysis was performed byKruskal-Wallis test (1952), considering $\mathrm{P} \leq 0.05$.

\subsection{Effectof growth regulatorson in vitroseedlings development}

To evaluate the effect of growth regulators on in vitro development, we transferred 30-day old seedlings, grown in Y3 medium, supplemented with
$30 \mathrm{gL}^{-1}$ sucrose to Magenta ${ }^{\circledR}$ jars containing $50 \mathrm{~mL}$ of Y3 medium (EEUWENS, 1976), without amino acids (modified Y3 medium). The medium was supplemented with 3.5 or $7 \mathrm{mgL}^{-1} \mathrm{GA}_{3}$ (gibberellic acid) andabsence or $1 \mathrm{mgL}^{-1} \mathrm{NAA}$ (naphthaleneacetic acid) combined with absence or $0.5 \mathrm{mgL}^{-1} \mathrm{BAP}$ (6-Benzylaminopurine). As an energy source, $30 \mathrm{gL}^{-1}$ sucrosewas used, the media was gelled with $0.6 \%$ agar, and $\mathrm{pH}$ was adjusted to 5.8. After inoculation, seedlings were maintained in a growth room chamberwith white light(photon irradiance of $40 \mu \mathrm{mol} \mathrm{m}^{-2} \mathrm{~s}^{-1}$ ) under 16-hour photoperiod at $27 \pm 2{ }^{\circ} \mathrm{C}$.

Seventy-five days after incubation, the following parameters were analyzed: shoots length, number of leaves, presence of roots, root length, fresh and dry weight of shoots and roots.

The experiment was conducted in a randomized block design with five replications of five seedlings each per treatment. Data were subjected to analysis of variance (ANOVA) and means were compared by Tukey test, at 5\% probability, using SISVAR program (FERREIRA, 2008).

\subsection{Acclimatization}

For acclimatization, 100 seedlings presenting roots and 100 seedlings presenting no roots, all grown in Y3 medium supplemented with $30 \mathrm{gL}^{-1}$ sucrose for 90 days were used. Seedlings were washed in running water to remove medium residues and transplanted into $56 \mathrm{~cm}^{3}$ polyethylene tubes containing pine bark substrate and the tubes were transferred to a greenhouse. After 60 days, survival rate of seedlings was assessed. Surviving seedlings were considered as acclimatized.

\section{RESULTS}

The addition of sucrose at different concentration or sorbitol to the culture medium was essential for oil palm embryos germination. As can be seen in Figure 1, treatments without sugar (control) presented no embryo germination.

High germination rate of zygotic embryos was observed in the medium supplemented with carbohydrates (Figure 1). Embryos cultured on MS medium containing $36 \mathrm{gL}^{-1}$ sorbitol presented $92 \%$ germination, however, it was not statistically different either from treatments on MS medium containing sucrose at concentration $30 \mathrm{gL}^{-1}$ with $76 \%$ germinated embryos

Revista Árvore, Viçosa-MG, v.38, n.6, p.1095-1102, 2014 


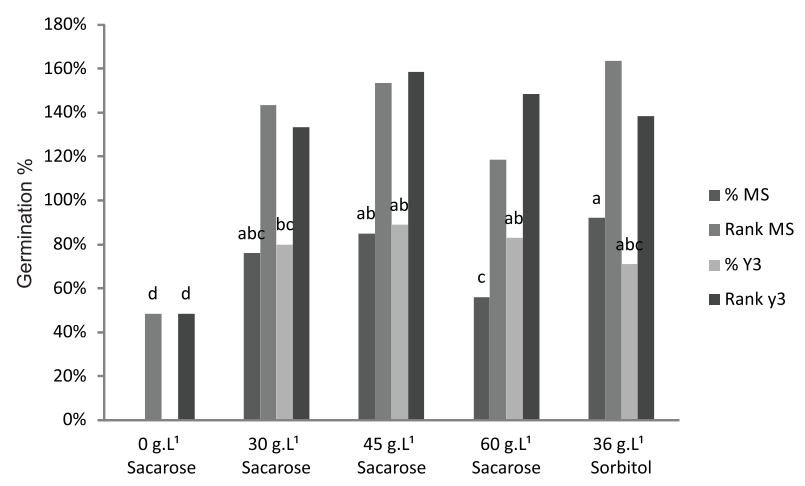

Figure 1 - In vitro germination percentage of E. oleifera $\mathrm{x}$ E. guineensis Jacq. hybrid Manicoré embryos inoculated on MS medium supplemented with carbohydrates. Means followed by the same letter do not differ statistically by Kruskal-Wallis test at $5 \%$.

Tabela 1 - Porcentagem de germinação in vitro de embriões de E. oleifera $x$ E. guineensis híbrido Manicoré, inoculados nos tratamentos com o meio de cultivo MS suplementado com carboidratos. Médias seguidas pela mesma letra não diferem estatisticamente pelo teste de Kruskall-Wallis a 5\%.

or at concentration $45 \mathrm{gL}^{-1}$ with $85 \%$ germination, or from treatments with Y3 medium supplemented with sucrose at all concentrations.

Regarding to seedling growth, the use of growth regulators promoted a favorable effect to the parameter shoot length (SL) making them different from the control. On one hand, the longest shoot $(6.2 \mathrm{~cm})$ was observed using $7.0 \mathrm{mg} \mathrm{L}^{-1} \mathrm{GA}_{3}$ (Table 1). On the other hand, the longest root $(3.6 \mathrm{~cm})$ was observed on the control treatment (Table 1). Number of leaves and the presence of roots presented no significant differences among treatments (Table 1). Although seedlings were more elongated in the presence of $\mathrm{GA}_{3}$, there was a reduced leaf area compared with seedlings grown in the other treatments, thus, this regulator negatively affected leaf area in in vitro explants (Figure 2).
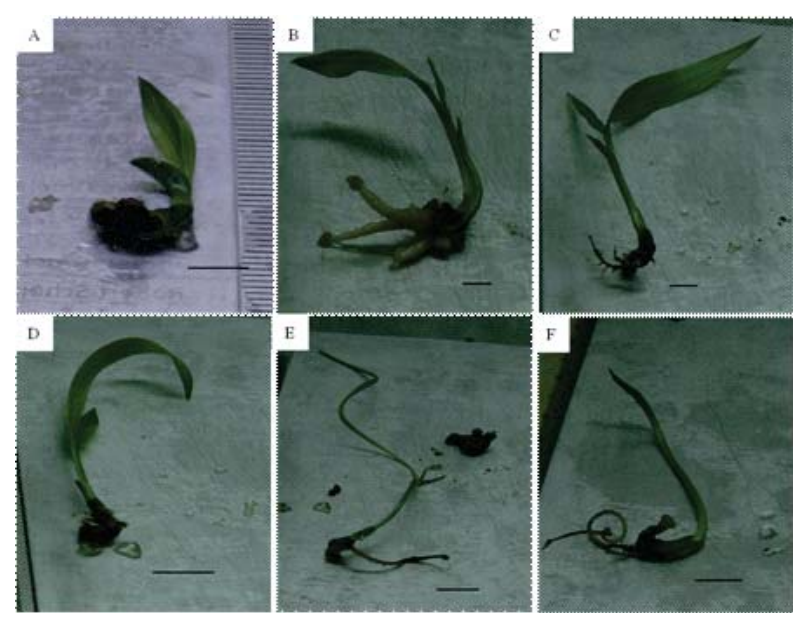

Figure 2 - In vitro germinated seedlings of E. oleifera $\mathrm{x}$ E. guineensis hybrid Manicoré 75 days old. A Seedling in $\mathrm{Y} 3$ culture medium without growth regulators; B - $5.37 \mu \mathrm{MNAA}$; $-2.21 \mu \mathrm{M}$ BAP;D$5.37 \mu \mathrm{M}$ NAAx2.21 $\mu \mathrm{MBAP}$;E-10 $\mu \mathrm{M} \mathrm{GA}_{3}$; and $\mathrm{F}-20 \mu \mathrm{M} \mathrm{GA}_{3}$. Bars $=1 \mathrm{~cm}$.

Tabela 2 - Plântulas germinadas de E. oleifera $x$ E. guineensis híbrido Manicoré in vitro com 75 dias de cultivo. A - Plântula em meio de cultivo Y3, ausência de reguladores de crescimento; $B-5,37 \mu M$ de $A N A ; C$ - 2,21 $\mu M$ de BAP;D- 5,37 $\mu M$ de ANA x 2,21 $\mu M$ de BAP;E- $10 \mu \mathrm{M}$ de $G A_{3}$; e F- $20 \mu \mathrm{M}$ de $G A_{3}$. Barras $=1 \mathrm{~cm}$.

Table 1 - Average valuesforshoot length (SL), leaf number (LN), root presence(RP) androot length(RL) of E.guineensis $\mathrm{x}$ E. oleifera seedlings after 45 days in culturewith growth regulators.

Tabela 1 - Valores médios docomprimento da parte aérea (CPA), número de folhas (NF), presença de raiz (PR) e comprimento de raízes $(C R)$ de plântulas de $\mathbf{E}$. oleifera $x \boldsymbol{E}$. guineensis, após 45 dias de cultivo na presença dos reguladores de crescimento.

\begin{tabular}{|c|c|c|c|c|}
\hline Treatment & $\mathrm{SL}(\mathrm{cm})$ & $\mathrm{LN}$ & $\mathrm{R}(\%)$ & $\mathrm{RL}(\mathrm{cm})$ \\
\hline Control & $2.0 \mathrm{~b}$ & $1.9 \mathrm{a}$ & $32 \mathrm{a}$ & $3.6 \mathrm{a}$ \\
\hline $1.0 \mathrm{mgL}^{-1} \mathrm{NAA}$ & $4.0 \mathrm{ab}$ & $2.3 \mathrm{a}$ & $34 \mathrm{a}$ & $1.6 \mathrm{~b}$ \\
\hline $0.5 \mathrm{mgL}^{-1} \mathrm{BA}$ & $4.4 \mathrm{a}$ & $1.9 \mathrm{a}$ & $30 \mathrm{a}$ & $2.1 \mathrm{~b}$ \\
\hline $1.0 \mathrm{mgL}^{-1} \mathrm{NAA}+0.5 \mathrm{mgL}^{-1} \mathrm{BA}$ & $3.9 \mathrm{ab}$ & $2.4 \mathrm{a}$ & $20 \mathrm{a}$ & $2.4 \mathrm{ab}$ \\
\hline $3.5 \mathrm{mgL}^{-1} \mathrm{GA}_{3}$ & $4.7 \mathrm{a}$ & $1.8 \mathrm{a}$ & 38 a & $2.7 \mathrm{ab}$ \\
\hline $7.0 \mathrm{mgL}^{-1} \mathrm{GA}_{3}$ & $6.2 \mathrm{a}$ & $1.9 \mathrm{a}$ & $20 \mathrm{a}$ & $1.8 \mathrm{~b}$ \\
\hline CV $(\%)$ & 42.1 & 41.2 & & 29.2 \\
\hline
\end{tabular}

Means followed by the same letters in columns do not differ significantly by Tukey test at $5 \%$ probability.

As médias seguidas pelas mesmas letras nas colunas não diferem significativamente entre si, pelo teste de comparação de médias de Tukey a $5 \%$ de probabilidade.

Revista Árvore, Viçosa-MG, v.38, n.6, p.1095-1102, 2014 
Regarding to seedlings biomass, we found no significant differences in fresh matter of shoots among treatments. However, when the roots were analyzed, an increase in the biomass of roots grown in the presence of auxins was observed. Addition of growth regulatorauxin in combination with cytokinin increased shoot dry matter in seedlings, however, this association did not similarly favor either root growth or dry matter (Table 2).

\section{DISCUSSION}

The germination rates obtained in this study $(92 \%)$ are highly significant when compared to results obtained with the conventional germination method(approximately $30 \%$ ), which is based on direct seed germination without embryo rescue (MARTINE et. al., 2009). Our results for germination BRS Manicoréhybrid (Elaeisguineensisx E. oleifera) using sorbitol as carbon source $(92 \%)$ confirm the high rate germination reported by Te-chato and Hilae (2007) with somatic embryos of E. guineensis hybrid Tenera.

Similar germinated rates of embryos $(80 \%)$ in $\mathrm{Y} 3$ medium supplemented with carbohydrates were found by Cardoso et al. (2010) when testing MS and Y3 media, either full or with half-strength. These trials showed higher germination rates $(85.18 \%)$ in full Y3 medium for E. guineensis hybrid CN514. Similar results were also obtained in zygotic embryos of peach palm (Bactrisgasipaes) when evaluating MS, Y3 and WH culture media (WHITE, 1942), where the highest germination rates $(95.5 \%)$ were found in Y3 medium. However, these values were not statistically different from those obtained on MS medium (STEINMACHER, 2005).

Our results are also in agreement with $\mathrm{Hu}$ and Ferreira (1998), which highlight the need for an exogenous source of sugars when embryos are immature, as they have no source of nutrients in their cotyledons. Nunes et al. (2008) observed that germination rate of immature embryos of jatropha (Jatrophacurcas L.) increased proportionally to increase of sucrose in the culture medium, with the highest rate $(83.68 \%)$ observed in the concentration $60 \mathrm{~g} \mathrm{~L}^{-1}$ sucrose. Pereira et al. (2006a) evaluated germination of mature and immature embryos of Astrocaryumule $i$ with increasing concentrations of sucrose, concluding that the culture medium supplemented with $15 \mathrm{gL}^{-1}$ resulted in higher germination rates of mature embryos while $30 \mathrm{gL}^{-1}$ provided better results for immature embryos.

Angelo et al. (2007) also evaluated different sources of carbohydrates such as glucose and sucrose associated with solid and liquid MS media for oil palm embryos and obtained better results with liquid MS medium supplemented with $20 \mathrm{gL}^{-1}$ or $30 \mathrm{gL}^{-1}$ glucose. Rego-Oliveira et al. (2003) assessed supplementation of culture medium with glucose, maltose and sucrose at different concentrations, concluding that the treatment with $60 \mathrm{gL}^{-1}$ sucrose was the most suitable for embryo germination of oncidiums (Oncidiumvaricosum).

Table 2-Shoot and root biomass of E. guineensis hydrid Manicoré seedlings maintained for 75 daysinin vitro culture mediumsupplemented withgrowth regulators. Mean valuesforshoots fresh weight (SFW), shootdry weight (SDW), root fresh weight (RFW), and rootdry weight (RDW) of seedlings ofdendezeiro 75 days

Tabela 2 - Biomassa de parte aérea e de raiz de plântulas de dendezeiro híbrido Manicoré aos 75 dias de cultivo in vitro, em meio de cultura suplementado com reguladores de crescimento. Valores médios demassa fresca de parte aérea (MFA), massa seca de parte aérea (MSA), massa fresca de raiz (MFR) emassa seca de raiz (MSR) de plântulas de dendezeiroaos 75 dias.

\begin{tabular}{|c|c|c|c|c|}
\hline Trataments & SFW(mg) & SDW(mg) & RFW(mg) & RDW(mg) \\
\hline Control & $300 \mathrm{a}$ & $21 \mathrm{c}$ & $20 \mathrm{~b}$ & $4 \mathrm{bc}$ \\
\hline $5.37 \mu \mathrm{M}$ NAA & $19 \mathrm{a}$ & $34 \mathrm{ab}$ & $71 \mathrm{a}$ & $12 \mathrm{ab}$ \\
\hline $2.21 \mu \mathrm{M} \mathrm{BA}$ & $20 \mathrm{a}$ & $27 \mathrm{bc}$ & $42 \mathrm{ab}$ & 8 abc \\
\hline $5.37 \mu \mathrm{M} \mathrm{NAA}+2.21 \mu \mathrm{M} \mathrm{BA}$ & 29 a & $41 \mathrm{a}$ & $26 \mathrm{~b}$ & $7 \mathrm{abc}$ \\
\hline $10 \mu \mathrm{M} \mathrm{GA}_{3}$ & $17 \mathrm{a}$ & $24 \mathrm{bc}$ & $21 \mathrm{~b}$ & $14 \mathrm{a}$ \\
\hline $20 \mu \mathrm{M} \mathrm{GA}_{3}$ & 19 a & $26 \mathrm{bc}$ & $18 \mathrm{~b}$ & $3 \mathrm{c}$ \\
\hline $\mathrm{CV}(\%)$ & 48.58 & 29.37 & 70.00 & 78.29 \\
\hline
\end{tabular}

Means followed by the same letters in columns do not differ significantly by Tukey test at $5 \%$ probability.

As médias seguidas pelas mesmas letras nas colunas não diferem significativamente entre si, pelo teste de comparação de médias de Tukey a $5 \%$ de probabilidade. 
The need for a smaller amount of sucrose in the culture medium may favor acclimatization future steps, as high concentrations can cause both structural and functional alterations in organs (POSPÍSILOVÁ et al., 1999). Therefore, our results are favorable since high germination rates were also obtained at the lowest concentration of sucrose assessed $\left(30 \mathrm{~g} \mathrm{~L}^{-1}\right)$ in both Y3 and MS culture media (Figure 1).

Regarding the effect of growth regulators on seedling growth, although $\mathrm{GA}_{3}$ provided a better shoots growth, the leaf area was reduced. Growth of seedlings in culture medium supplemented with gibberellins was not accompanied by leaf area expansion, thus requiring a balance of regulators in the culture medium. This fact may be related to the role of gibberellins, which generally promote cell elongation (TORRES et al., 1998) and probably promoted a higher stem growth at the expense of leaf expansion.

There was no increase in number of leaves in seedlings grown in the medium supplemented with BAP, although this growth regulator is related to leaf formation (TORRES et al., 1999). In addition, we found no significant root formation in medium with NAA auxins, although it is related to root formation (ASSIS; TEIXEIRA, 1998).

Similar results were found by Pereira et al. (2006b), who evaluated shoot length of cat's claw (Uncariatomentosa) after 45 days of cultivation. The authors observed higher shoot length using $\mathrm{GA}_{3}$, although there were no statistical differences in the absence of this regulator. Ledo et al. (2001) evaluated in vitroseedling growth of açaípalm (Euterpeoleracea) with NAA and BAP regulators and reported higher shoot length in the medium withNAA $(2,68 \mu \mathrm{M})$ plus $\operatorname{BAP}(1,11 ; 1,55 ; 2,22 \mu \mathrm{M})$. Reis et al. (2008) evaluated shoot length of lemon balm (Melissa officinalis) on MS medium in the presence and absence of BAP and concluded that shoot length was higher with BAP.

Regarding biomass, different results were obtained by Villa et al. (2005), who observed that shoot dry weight of blackberry (Rubusfruticosus) was higher in the culture medium supplemented with $1 \mathrm{mgL}^{-1}$ BAP.

As for acclimatization, previous rooting of seedlings is crucial for successful process. According to Costa et al. (2008), high survival rates are found during the acclimatization phase, when in vitro elongation and rooting occur in most species. Similar survival rates were also found by Thuzar et al.(2011) in oil palms over six centimeters long acclimated in substrates of sand, coconut husk and carbonized rice bran (1:1:1).Steinmacher (2005) also found that seedlings of peach palm (Bactrisgasipaes) under six cm long obtained from in vitro culture had a lower survival rate.

Further studies are needed on the hormonal balance of auxins and cytokinins to optimize shoot and root development of oil palm seedlings.

\section{CONCLUSION}

Supplemental carbohydrate sources are essential to promote high in vitro germination rates of zygotic embryos of oil palm hybrid BRS Manicoré.

Supply of growth regulators promoted higher shoot growth.

Rootedseedlings are more apt to acclimatization phase since they had $85 \%$ survival rate, which demonstrates the need for root system formation.

\section{ACKNOWLEDGEMENT}

To the undergraduate student Daniella Cristina de Souza Borges for the contribution in the experiments and to the funding agencies FAPEMIG, CNPq e CAPES.

\section{REFERENCES}

ANGELO, P. C. S.; MORAES, L. A. C.; SOUSA, N. R.; LOPES, R.; CUNHA, R. N. V. Resgate de embriões híbridos de dendezeiro $x$ caiaué. Manaus: SPI/Embrapa, 2007. 4 p. (Comunicado Técnico, 49)

ASSIS, T. F.; TEIXEIRA, S. L. Enraizamento de plantas lenhosas. In: TORRES, A. C.; CALDAS, L. S.; BUSO, J. A. (Ed.). Cultura de tecidos e transformação genética de plantas. Brasília: SPI/Embrapa, 1998. p.184-185.

BARBOZA, S. B. S. C.; GRACIANO-RIBEIRO, D.; TEIXEIRA, J. B.; PORTES, T. A.; SOUZA, L. A. C. Anatomia foliar de plantas micropropagadas de abacaxi. Pesquisa Agropecuária

Brasileira, v.41, n.2, p.185-194, 2006.

BEAKBANE, A. B.; SLATER, C. H. W.; POSNETTE, A. F.. Mycoplasmas in the phloem of coconut, Cocos nucifera L., with lethal yellowing 
disease. Journal Horticultural Science, v.47, p.265, 1972.

BOARI, A. J. Estudos realizados sobre o amarelecimento fatal do dendezeiro (Elaeis guineensis Jacq.). Belém: Embrapa, 2008.59p. (Documentos, 348).

CARDOSO, J. N. O.; MIRANDA, V. S.; LEMOS, O. F.; COELHO, I. L. Obtenção de plântulas de híbridos de dendezeiro por cultivo in vitro. Revista Ciências Agrárias, v.53, n.2, p.177$181,2010$.

COLLARES, D. Produção de cultivares e sementes de dendê na Embrapa. Agroenergia em Revista, v.2, p.30-31, 2011.

EEUWENS, C. J. Effects of organic nutrients and hormones on growth and delopment of tissue explants from coconut (Cocos nucifera) and date (Phoenyx dactylifera) palms cultured in vitro. Physiologia Plantarum, v.42, n. 2, p.173-178, 1976.

FERREIRA, D. F. SISVAR: Um programa para análise e ensino de estatística. Revista Symposium, v. 6, n. 6, p.36-4, 2008.

FURLAN, L. F. Potencialidades regionais estudo de viabilidade econômica dendê. Brasília: SUFRAMA, 2003. 12p.

TASHTOUSH, G.; AL-WIDYAN, M. I.; ALSHYOUKH. A Combustion performance and emissions of ethyl ester of a waste vegetable oil in a water-cooled fumace. Applied Thermal Engineer, v.23, n.3, p.285-293, 2003.

HU, C. Y.; FERREIRA, A. G. Cultura de embriões. In: TORRES, A. C.; CALDAS, L. S.; BUSO, J. A. (Ed.). Cultura de tecidos e transformação genética de plantas. Brasília: SPI/Embrapa, 1998. p.371-393.

KRUSKAL, W. H.; WALLIS, W. A. Use of ranks in one-criterion variance analysis. Journal of the American Statistical Association, v.260, n.47, p.583-621, 1952.

KONAN, E. E.; DURAND-GASSELIN, T; KOUADIO, J. Y.; FLORI, A.; RIVAL, A. A modeling approach of the in vitro conversion of oil palm (Elaeis guineensis) somatic embryos. Plant Cell, Tissue and Organ Culture. v. 84, n.1, p. 99-112, 2005.

LEDO, A. S.; LAMEIRA, O. A.; BENBADIS, A. K.; MENEZES, I. C.; LEDO, C. A.S.; OLIVEIRA, M.S. P. Cultura in vitro de embriões zigóticos de açaizeiro. Revista Brasileira de Fruticultura, v.23, n.3, p.468-472, 2001.

LIN, H. C.; MORILLO, F.; DUSSERT, F.; TRANCHANT-DUBREUIL, C.; TREGEAR, J. W.; TRANBARGER, T. J. Transcriptome analysis during somatic em- bryogenesis of the tropical monocot Elaeis guineensis: evidence for conserved gene functions in early development. Plant Molecular Biology, v.70, n.1-2, p.173-192, 2009.

LUIS, Z. G.; BEZERRA, K. M. G.; SCHERWINSKIPEREIRA, J. E. Adaptability and leaf anatomical features in oil palm seedlings produced by embryo rescue and pre-germinated seeds. Brazilian Journal Plant Physiology, v.22, n.3, p.209-215, 2010.

MARTINE, M. B.;LAURENT, K. K.; PIERRE, B, J.; EUGENÉ, K. K.; HILAIRE, K. T.; JUSTIN, K. Y. Effect of storage and heat treatments on the germination of oil palm (Elaeis guineensis Jacq.) seed. African Journal of Agricultural Research, v. 4, n. 10, p. 931-937, 2009.

MURASHIGE, T.; SKOOG, F. A revised médium for rapid growth and bioassays with tobacco tissue cultures. Physiologia Plantarum, v. 15, n.3, p.473-497, 1962 .

NUNES, C. F.; PASQUAL, M.; SANTOS, D. N.; CUSTÓDIO, T. N.; ARAUJO,A. G. Diferentes suplementos no cultivo in vitro de embriões de pinhão-manso. Pesquisa Agropecuária Brasileira, v.43, n.1, p.9-14, 2008.

PEREIRA, J. E. S.; RODRIGUES, F. A.; PASQUAL, M. NUNES, C. F.; ARAUJO, A. G. Germinação in vitro de embriões zigóticos de murmuru (Astrocaryum ulei). Ciência e Agrotecnologia, v.30, n.2, p.251-256, 2006a.

PEREIRA, R. C. A.; PAIVA, R.; STEIN, V. C.; NERY, F. C.; NOGUEIRA, R. C.; OLIVEIRA, L. M. Explante no alongamento in vitro de Uncaria guianensis (AUBLET) Gmelin Rubiaceae (unha-de-

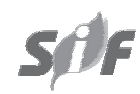

Revista Árvore, Viçosa-MG, v.38, n.6, p.1095-1102, 2014 
gato). Ciência e Agrotecnologia, v.30, n.4, p.637-642, 2006b.

POSPÍSILOVÁ, J.; TICHÁ, I.; KADLECEK, P.; HAISEL, D.; PLZÁKOVÁ, S. Acclimatization of micropropagated plants to ex vitro conditions. Biologia Plantarum, v.42, n.4, p.481-497, 1999

REGO-OLIVEIRA, L. V.; FARIA, R. T.; FONSECA, I. C. B.; SACONATO, C. Influência da fonte e concentração de carboidrato no crescimento vegetativo e enraizamento in vitro de Oncidium varicosum Lindl.(Orchidaceae). Semina:

Ciências Agrárias, v.24, n.2, p.265-272, 2003.

RAE, C.; BRADLEY, F. “Energy autonomy in sustainable communities; A Review of Key Issues." Renewable and Sustainable Energy Reviews, v.16, n.9, p.6497-6506, 2013.

REIS, E. S.; PINTO, J. E. B. P.; ROSADO, L. D. S.; CORREA, R. M. Influência do meio de cultura na germinação de sementes in vitro e taxa de multiplicação de Melissa officinalis L. Revista Ceres, v.55, n.3, p.160-167, 2008.

SHIN, K. S.; PARK, S.Y.; PAEK, K.Y. Sugar metabolism, photosynthesis, and growth of in vitro plantlets of Doritaenopsis under controlled microenvironmental conditions. In Vitro

Cellular Developmental Biology Plant, v.49, n.4, p.445-454, 2013.

SOARES, J. D. R., RODRIGUES, F. A.; PASQUAL, M.; NUNES, C. F.; ARAUJO, A. G. Germinação de embriões e crescimento inicial in vitro de macaúba. Ciência Rural, v.41, n.5, p.773-778, 2011.

STEINMACHER, D. A. Germinação in vitro, criopreservação e embriogênese somática em pupunha. 2005. $123 \mathrm{f}$. Dissertação (Mestrado em Recursos genéticos
Vegetais) - Universidade Federal de Santa Catarina, Florianópolis, 2005.

TE-CHATO, S.; HILAE, A. High-frequency plant regeneration through secondary somatic embryogenesis in oil palm (Elaeis guineensis Jacq. var. tenera). Journal of Agricultural Technology, v.3, n.2, p.345-357, 2007.

TRUONG, Q.; KOCH, K.; YOON, J. M.; EVERARD, J. D.; SHANKS, J. V. Influence of carbon to nitrogen ratios on soybean somatic embryo (cv. Jack) growth and composition.Journal of Experimental Botany, v.64, n.10, p.2985-2995, 2013.

THUZAR, M.; VANAVICHIT, A.; TRAGOONRUNG, S.; JANTASURIYARAT, C. Efûcient and rapid plant regeneration of oil palm zygotic embryos cv. 'Tenera' through somatic embryogenesis. Acta Physiologiae Plantarum, v.33, n.1, p.123-128, 2011.

TORRES, A. C.; CALDAS, L. S.; BUSO, J. A. A cultura de tecidos e transformação genética de plantas. Brasília: EMBRAPA SPI/ EMBRAPA CNPH, 1998. 2v. 864 p.

TORRES, A. C.; CALDAS, L. S.; BUSO, J. A. (Ed.). Cultura de tecidos e transformação genética de plantas. Brasília, DF: EMBRAPA SPI/EMBRAPA-CNPH, 1999. 2v. 354p.

WHITE, P. R. Plant tissue culture. Annual Review of Biochemistry, v.11, p.615-628, 1942.

VILLA, F.; ARAÚJO, A. G.; PIO, L. A. S.; PASQUAL, M. Multiplicação in vitro da amoreira-preta 'Ébano' em diferentes concentrações de meio MS e BAP. Ciência e Agrotecnologia, v.29, n.3, p.582-589, 2005. 